\title{
Net Loss of $\mathrm{CaCO}_{3}$ from a subtropical calcifying community due to seawater acidification: mesocosm-scale experimental evidence
}

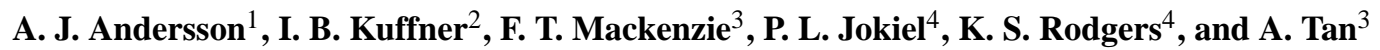 \\ ${ }^{1}$ Bermuda Institute of Ocean Sciences, St. George's, Bermuda, UK \\ ${ }^{2}$ US Geological Survey, Florida Integrated Science Center, St. Petersburg, FL, USA \\ ${ }^{3}$ Department of Oceanography, University of Hawaii, Honolulu, HI, USA \\ ${ }^{4}$ Hawaii Institute of Marine Biology, Kaneohe, HI, USA
}

Received: 31 December 2008 - Published in Biogeosciences Discuss.: 23 February 2009

Revised: 11 August 2009 - Accepted: 12 August 2009 - Published: 27 August 2009

\begin{abstract}
Acidification of seawater owing to oceanic uptake of atmospheric $\mathrm{CO}_{2}$ originating from human activities such as burning of fossil fuels and land-use changes has raised serious concerns regarding its adverse effects on corals and calcifying communities. Here we demonstrate a net loss of calcium carbonate $\left(\mathrm{CaCO}_{3}\right)$ material as a result of decreased calcification and increased carbonate dissolution from replicated subtropical coral reef communities $(n=3)$ incubated in continuous-flow mesocosms subject to future seawater conditions. The calcifying community was dominated by the coral Montipora capitata. Daily average community calcification or Net Ecosystem Calcification $\left(\mathrm{NEC}=\mathrm{CaCO}_{3}\right.$ production - dissolution) was positive at $3.3 \mathrm{mmol} \mathrm{CaCO}_{3} \mathrm{~m}^{-2} \mathrm{~h}^{-1}$ under ambient seawater $p \mathrm{CO}_{2}$ conditions as opposed to negative at $-0.04 \mathrm{mmol} \mathrm{CaCO}_{3} \mathrm{~m}^{-2} \mathrm{~h}^{-1}$ under seawater conditions of double the ambient $p \mathrm{CO}_{2}$. These experimental results provide support for the conclusion that some net calcifying communities could become subject to net dissolution in response to anthropogenic ocean acidification within this century. Nevertheless, individual corals remained healthy, actively calcified (albeit slower than at present rates), and deposited significant amounts of $\mathrm{CaCO}_{3}$ under the prevailing experimental seawater conditions of elevated $p \mathrm{CO}_{2}$.
\end{abstract}

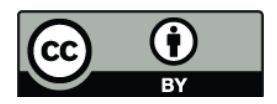

Correspondence to: A. J. Andersson (andreas.andersson@bios.edu)

\section{Introduction}

A substantial fraction of the $\mathrm{CO}_{2}$ released to the atmosphere from human activities is taken up by the ocean (e.g., Mackenzie et al., 2001; Sabine et al., 2004). $\mathrm{CO}_{2}$ in solution produces carbonic acid $\left(\mathrm{H}_{2} \mathrm{CO}_{3}\right)$, which is a weak acid and results in a decrease in seawater $p \mathrm{H}$ (increasing acidity) and conversion of carbonate ions $\left(\mathrm{CO}_{3}^{2-}\right)$ to bicarbonate $\mathrm{HCO}_{3}^{-}$ ions. A decrease in $\mathrm{CO}_{3}^{2-}$ concentration produces a drop in the seawater saturation state with respect to carbonate minerals $(\Omega)$, which is the quotient of the product of the seawater concentration of calcium and carbonate ions and an experimentally determined stoichiometric solubility product $\left(\Omega=\left[\mathrm{Ca}^{2+}\right]\left[\mathrm{CO}_{3}^{2-}\right] / K_{s p}^{*}\right)$. Simplified, the seawater carbonate saturation state index can provide information on the rates at which marine calcifiers can deposit skeletons and shells of $\mathrm{CaCO}_{3}$, or the opposite, the rates of dissolution and disintegration of these phases. Based on thermodynamic principles, precipitation of $\mathrm{CaCO}_{3}$ is expected when $\Omega>1$ and dissolution when $\Omega<1$. Future model projections suggest that surface seawater $\mathrm{pH}$ will decrease $0.5-0.7 \mathrm{pH}$ units relative to pre-industrial conditions in the next couple of centuries under a Business-As-Usual (BAU) $\mathrm{CO}_{2}$ emission scenario (Caldeira and Wickett, 2003; Andersson, et al., 2005). Simultaneously, seawater saturation state with respect to a variety of carbonate minerals will decrease and seawater could become undersaturated in many environments with respect to high $\mathrm{Mg}$-calcite minerals and even aragonite (Andersson et al., 2005; Orr et al., 2005; Morse et al., 2006). As a result, the ability to calcify and the rates of calcification among marine calcifiers are expected to decrease

Published by Copernicus Publications on behalf of the European Geosciences Union. 
significantly. Additionally, dissolution of carbonate sediments, structures, and even individual organisms could increase (Andersson et al., 2003, 2005; Jokiel et al., 2008). Despite the fact that surface seawater is supersaturated with respect to most naturally occurring carbonate mineral phases at present, dissolution is an ongoing process in sediments and microenvironments due to microbial metabolic activity (producing $\mathrm{CO}_{2}$ ) and actively boring endoliths (e.g., Alexandersson, 1975a, b; Morse and Mackenzie, 1990; Tribollet et al., 2008). These biological activities lower seawater carbonate saturation state and create corrosive conditions with respect to carbonate minerals that subsequently could undergo dissolution.

Future projected changes in calcification and carbonate dissolution resulting from ocean acidification could be drastic and sufficiently large so that coral reef communities and carbonate ecosystems in general could become subject to a net loss of $\mathrm{CaCO}_{3}$ material (Kleypas et al., 1999; Andersson et al., 2005, 2006, 2007; Yates and Halley, 2006; Hoegh-Guldberg et al., 2007; Silverman et al., 2009). Despite the fact that it is more or less certain carbonate dissolution will increase in response to ocean acidification, the effect of ocean acidification on carbonate dissolution rates has received relatively little attention compared to the effect on the ability of organisms to calcify. This is despite modeling studies (e.g., Andersson et al., 2005, 2006; Silverman et al., 2009) showing that the net ecosystem calcification $\left(\mathrm{NEC}=\mathrm{CaCO}_{3}\right.$ production - dissolution) of global carbonate ecosystems could become negative in the future.

In the present study, we investigate the effects of future seawater conditions anticipated by the end of the present century and beyond on the NEC, or what typically also is referred to as net community calcification (G), of a typical subtropical coral reef community including its sediments. The calcifying community was replicated and incubated in mesocosms over a complete, 24-h, diel cycle.

\section{Methods}

The present diel investigation (21 to 22 June 2006) was a part of a longer term ocean acidification experiment conducted at the Hawaii Institute of Marine Biology (HIMB) at Moku O Loe (Coconut Island), Kaneohe Bay, Hawaii $\left(21.4^{\circ} \mathrm{N}, 157.8^{\circ} \mathrm{W}\right)$ between 31 October 2005 and $8 \mathrm{Au}-$ gust 2006 (Jokiel et al., 2008; Kuffner et al., 2008). Six $1.165 \times 1.165 \times 0.460 \mathrm{~m}$ fiberglass mesocosm tanks (water level at $0.35 \mathrm{~m}$; Fig. 1) located in full sunlight were continuously supplied with flowing seawater pumped from approximately $2 \mathrm{~m}$ depth at the edge of the Coconut Island coral reef at a rate of approximately 7 to $81 \mathrm{~min}^{-1}$ per mesocosm with a turnover rate of approximately $1 \mathrm{~h}$. The seawater inflow is located at the bottom in the center of each mesocosm (see Smith et al., 1977 for details on the mesocosm system). Seawater is injected under pressure at a ver-

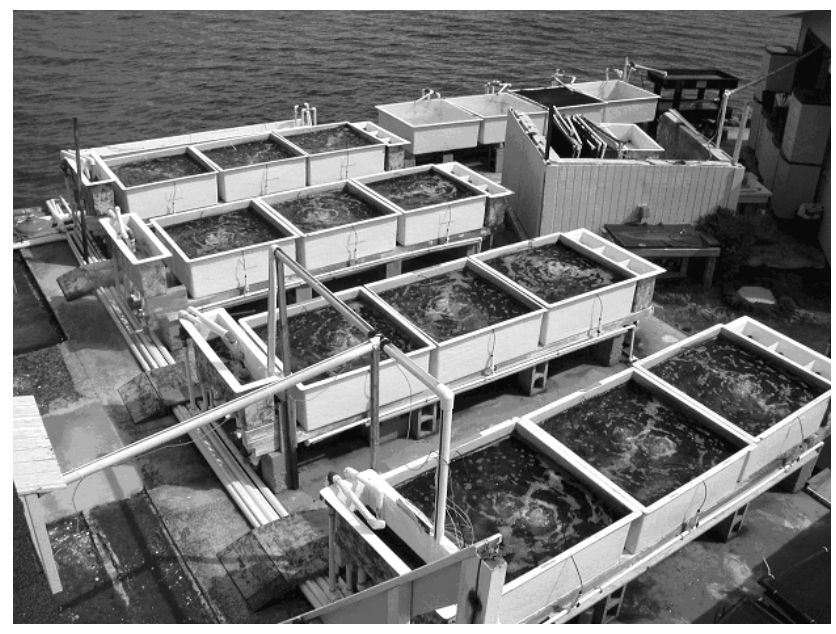

Fig. 1. Continuous-flow mesocosm facility at Hawaii Institute of Marine Biology (HIMB).

tical angle, which ensures a uniform and well-mixed system as confirmed from measurements of chemical and environmental parameters (i.e., there are no gradients in chemical and environmental parameters throughout the mesocosms). Three mesocosms were randomly chosen to be maintained at an ambient chemical state with respect to seawater $p \mathrm{CO}_{2}$, $\mathrm{pH},\left[\mathrm{CO}_{3}^{2-}\right]$, and $\Omega$. The remaining three mesocosms were maintained at a chemical state (with respect to these parameters) anticipated under a doubling of ambient seawater $p \mathrm{CO}_{2}$ conditions. The carbonic-acid system was manipulated by constant addition of diluted $\mathrm{HCl}(1.1 \mathrm{~N})$ using a 205CA Watson Marlow multi-channel peristaltic pump at a rate of $\sim 1.3 \mathrm{ml} \mathrm{min}^{-1}$ to the seawater inflow pipes of the treatment mesocosms. The addition of acid produced a decrease in the seawater total alkalinity (TA) and a subsequent shift in the distribution of dissolved inorganic carbon species similar to that resulting from uptake of anthropogenic $\mathrm{CO}_{2}$ (e.g., Langdon and Atkinson, 2005). Maintaining seawater flow and acid addition at constant rates ensured that natural fluctuations in seawater chemistry on both diel and seasonal cycles were preserved throughout the duration of the experiment (Kayanne et al., 1995; Frankignoulle et al., 1996; Ohde and van Woesik, 1999; Bates, 2002). In addition to inflow of ambient seawater at 7 to $81 \mathrm{~min}^{-1}$ to the control mesocosms, these tanks received regular fresh water via the seawater inflow pipes at the same rate acid was added to the treatment mesocosms (i.e., $1.3 \mathrm{ml} \mathrm{min}^{-1}$ ).

Environmental and chemical parameters were measured in each mesocosm at least weekly in the long-term experiment to ensure that the desired treatment conditions were effective (Jokiel et al., 2008; Kuffner et al., 2008). During the diel experiment, in situ measurements were made and seawater samples collected every 2 and $4 \mathrm{~h}$, respectively, in each mesocosm and also in the seawater intake lines for a $24-\mathrm{h}$ period of time. Measured parameters included temperature and 
salinity (YSI 30 salinity/conductivity/temperature; $\pm 0.1^{\circ} \mathrm{C}$; $\pm 0.1 \mathrm{ppt}$ ), dissolved oxygen (YSI 95 Dissolved Oxygen Microelectrode Array Model; $\pm 0.2 \mathrm{mg} \mathrm{L}^{-1}$ ), $\mathrm{pH}_{\mathrm{NBS}}$ (Accumet AP72 $\mathrm{pH} / \mathrm{mV} /$ temperature meter and Oakton fully enclosed $\mathrm{Ag} / \mathrm{AgCl}$ combination electrode; $\pm 0.01 \mathrm{pH}$ units), TA and nutrients $\left(\mathrm{PO}_{4}^{3-}, \mathrm{NO}_{2}^{-}, \mathrm{NO}_{3}^{-}, \mathrm{NH}_{4}\right.$, and $\mathrm{Si}(\mathrm{OH})_{4}$; all data are presented in supplementary Table $\mathrm{S} 1$ ). TA samples were collected in $200 \mathrm{ml} \mathrm{Kimax}$ brand glass sample bottles and fixed with $100 \mu \mathrm{L}$ saturated $\mathrm{HgCl}_{2}$ solution. Nutrient samples were filtered using $0.45 \mu \mathrm{m}$ Millipore filters, stored in $60 \mathrm{ml}$ opaque amber plastic bottles and kept frozen until analysis. Nutrient analyses were conducted by the Marine Chemistry Laboratory at the University of Washington using an autoanalyzer (Technicon Model AAII). TA was determined by potentiometric acid titration similar to the procedures described by Grashoff et al. (1983) and DOE (1994) using a Brinkmann Methrohm Dosimat and an Orion Expandable Ion Analyzer EA920 with an Accumet calomel combination electrode. The acid $(\sim 0.1 \mathrm{~N} \mathrm{HCl}$ with an ionic strength of 0.7) was standardized against certified reference material (CRM) prepared in the laboratory of Andrew Dickson at Scripps Institute of Oceanography. CRMs were analyzed every 7 samples to ensure accuracy and precision of the titration system. The $1 \sigma$ precision of TA analysis was $0.11 \%$ $\left(\sim 2.5 \mu \mathrm{mol} \mathrm{kg}^{-1} ; n=14\right)$. Seawater dissolved inorganic carbon parameters and saturation state with respect to carbonate minerals were calculated based on $\mathrm{pH}_{\mathrm{NBS}}$ and TA using the program CO2SYS (Lewis and Wallace, 1998) and stoichiometric dissociation constants defined by Mehrbach et al. (1973) and refit by Dickson and Millero (1987). Constants were redefined on the NBS scale. $\mathrm{pH}_{\mathrm{NBS}}$ measurements in seawater are not ideal for cross-comparison between studies or for calculating the carbonic acid system in seawater owing to the difference in ionic strength between these mediums (i.e., buffer solution and seawater) and associated problems with electrode liquid junction potential (e.g., Zeebe and Wolf-Gladrow, 2003). However, the calculated ambient daytime $p \mathrm{CO}_{2}$ levels in the present study agreed well with independent measurements by a NOAA PMEL $p \mathrm{CO}_{2}$ buoy located nearby to the seawater intake line (see supplemental information of Kuffner et al., 2008) suggesting that the data are reasonably accurate and robust. Furthermore, it is the relative difference between treatment and control mesocosms that is most important in the present investigation. This difference is little affected by the shortcomings of the $\mathrm{pH}$ measurements.

The calcifying community of each mesocosm was comprised of an identical number of corals (Pocillopora damicornis and Montipora capitata) and rhodoliths (i.e., crustose coralline algae; e.g., Lithophyllum cf. pallescens, Hydrolithon sp., and Porolithon sp.) introduced to the mesocosms well before the present diel study started ( 2 weeks to 8 months). The corals covered $20-30 \%$ of the bottom of the tanks, which is a typical coral cover for Hawaiian Reefs. Other organisms were also present in each mesocosm as a result of natural settlement of larvae on the mesocosm walls from the continuous flowing seawater. For example, at the end of the long-term experiment (beginning of August), turf algae covered $15-17 \%$ of the walls in the mesocosms, bivalves $4-6 \%$, and crustose coralline algae $25 \%$ and $4 \%$ in the control and treatment mesocosms, respectively (Jokiel et al., 2008; Kuffner et al., 2008). 53\% and 78\% of the walls remained as bare substratum in the control and the treatment mesocosms, respectively. In addition, barnacles, vermetids, tunicates, polychaetes, crustaceans, mollusks and other organisms had recruited into a complex community as described by Smith et al. (1977) and reported in Jokiel et al. (2008). Nevertheless, forty colonies of M. capitata (Fig. 2) were by far the most dominant calcifying component of each mesocosm in terms of both total mass and rate of calcification. Furthermore, a thin sediment layer of a few millimeters thickness comprised of very fine-grained carbonate material and organic debris was present at the bottom of each mesocosm. Some of this material came in through the seawater intake lines and settled out in the mesocosms, and some was produced in situ by mechanical disintegration and as detritus from epiphytic borings of substrates of the biological community in the mesocosms.

NEC was calculated according to the procedure outlined in Fig. 3 (see also supplementary Table S2). Statistical analysis of measured parameters was conducted using two-way analysis of variance (ANOVA) with mesocosms and time as fixed factors. Tukey's 1-degree of freedom test for non-additivity was used to evaluate interactions between the fixed factors. A priori contrasts of control and treatment mesocosms were used to evaluate the effects of treatment and formed the basis of the main statistical results reported here.

\section{Results}

\subsection{Seawater $\mathrm{CO}_{2}$ parameters}

Acidification of seawater in the treatment mesocosms resulted in a shift in the distribution of dissolved inorganic carbon parameters and produced conditions in the seawater with respect to $p \mathrm{CO}_{2}, \mathrm{pH}, \mathrm{CO}_{3}^{2-}$ and carbonate saturation state that could become reality by the end of this century and beyond as a result of continued anthropogenic emissions of $\mathrm{CO}_{2}$ (Table 1; Fig. 4a, b). All these parameters were statistically significantly different between treatment and control mesocosms. Because of natural changes in seawater chemistry on diel time scales owing to metabolic processes (Kayanne et al., 1995; Frankignoulle et al., 1996; Ohde and van Woesik, 1999; Bates, 2002), neither control nor treatment chemical conditions were maintained at constant levels, but as anticipated varied significantly throughout a diel cycle. Both control and treatment mesocosms were subject to $p \mathrm{CO}_{2}$ levels significantly higher than the current atmospheric $p \mathrm{CO}_{2}$ and a doubling of the current 


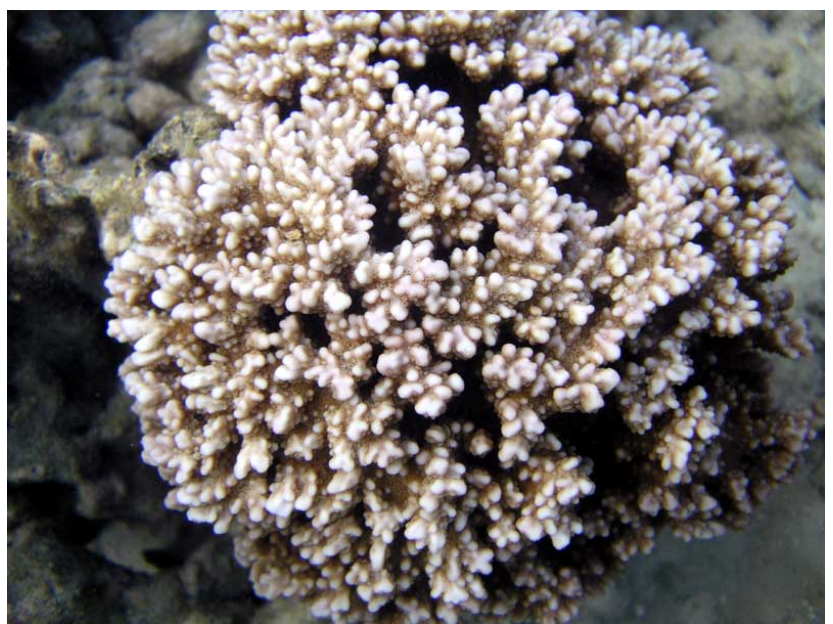

Fig. 2. The calcifying community of each mesocosm was dominated by forty colonies of Montipora capitata.

level, respectively. However, it is important to realize that many coral reef environments are subject to surface seawater $p \mathrm{CO}_{2} \mathrm{~s}$ much higher than the overlying atmosphere due to processes such as calcification and remineraliztion of organic matter. For example, measurements in Kaneohe Bay made by E. DeCarlo and colleagues at the University of Hawaii and NOAA PMEL have on occassion shown surface seawater $p \mathrm{CO}_{2}$ exceeding $1000 \mu \mathrm{atm}$ at present time (http://www. pmel.noaa.gov/co2/coastal/kbay/CRIMP2_all.htm). In the present study, the absolute difference between treatment and control mesocosms appeared greater at night than during the day, but the relative difference remained essentially constant throughout the 24-h period. On average, $p \mathrm{CO}_{2}$ in the treatment mesocosms exceeded control mesocosms by $104 \pm 11 \%$ (daily average (d.a.) $p \mathrm{CO}_{2}=568 \mu \mathrm{atm}$ and $1147 \mu \mathrm{atm}$ in control and treatment, respectively), $\mathrm{pH}$ was lower by $3.6 \pm 0.2 \%$ (d.a. $\mathrm{pH}=8.0$ and 7.76 in control and treatment, respectively), and $\left[\mathrm{CO}_{3}^{2-}\right]$ and aragonite saturation state were both lower by $46 \pm 3 \%$ (d.a. $\left[\mathrm{CO}_{3}^{2-}\right]=177 \mu \mathrm{mol} \mathrm{kg}^{-1}$ and $97 \mu \mathrm{mol} \mathrm{kg}^{-1}$; d.a. $\Omega_{\text {aragonite }}=2.8$ and 1.4 in control and treatment, respectively). Thus, the treatment effect represented a doubling of ambient conditions with respect to $p \mathrm{CO}_{2}$. The observed daytime and nighttime $p \mathrm{CO}_{2}$ in treatment mesocosms roughly correspond to equilibrium levels with the atmosphere projected for year 2100 under emission scenarios B1 and A1FI, respectively (IPCC, 2001). The seawater saturation state with respect to aragonite was supersaturated in both control $\left(\Omega_{\text {arag }} \sim 3.6\right)$ and treatment $\left(\Omega_{\text {arag }} \sim 2.1\right)$ mesocosms during daytime. While control mesocosms remained supersaturated at night with respect to this mineral phase $\left(\Omega_{\mathrm{arag}} \sim 2\right)$, treatment mesocosms reached values close to equilibrium $\left(\Omega_{\text {arag }} \sim 1\right)$. Consequently, the seawater was undersaturated with respect to carbonate minerals more soluble than aragonite, such as high $\mathrm{Mg}$-calcite phases, at this time and potentially subject to dissolution.

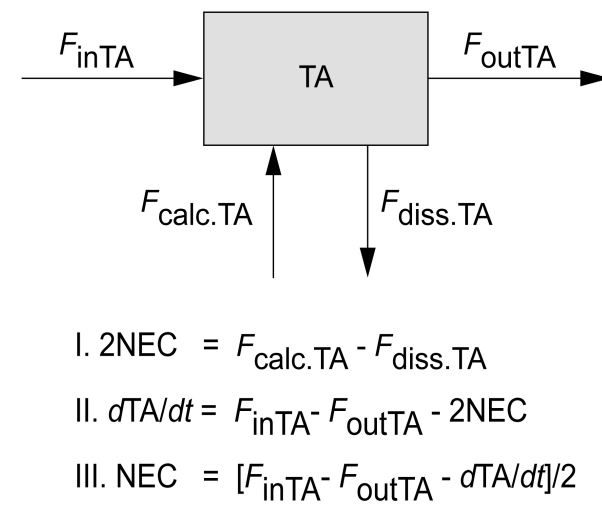

Fig. 3. The mesocosms are well mixed systems and can be represented by a simple box model. Assuming that changes in total alkalinity (TA) are uniquely attributed to calcification or carbonate dissolution, the Net Ecosystem Calcification (NEC) can be easily calculated according to Eqs. I to III by measuring the TA of the inflowing $\left(F_{\text {inTA }}\right)$ and outflowing $\left(F_{\text {outTA }}\right)$ seawater, and the change in TA per unit time $(d \mathrm{TA} / d t)$ of the seawater in the mesocosms between consecutive sampling times. The NEC is multiplied by 2 owing to the fact that for every $1 \mathrm{~mol}$ of $\mathrm{CaCO}_{3}$ precipitated or dissolved, $2 \mathrm{~mol}$ of TA is produced or removed.

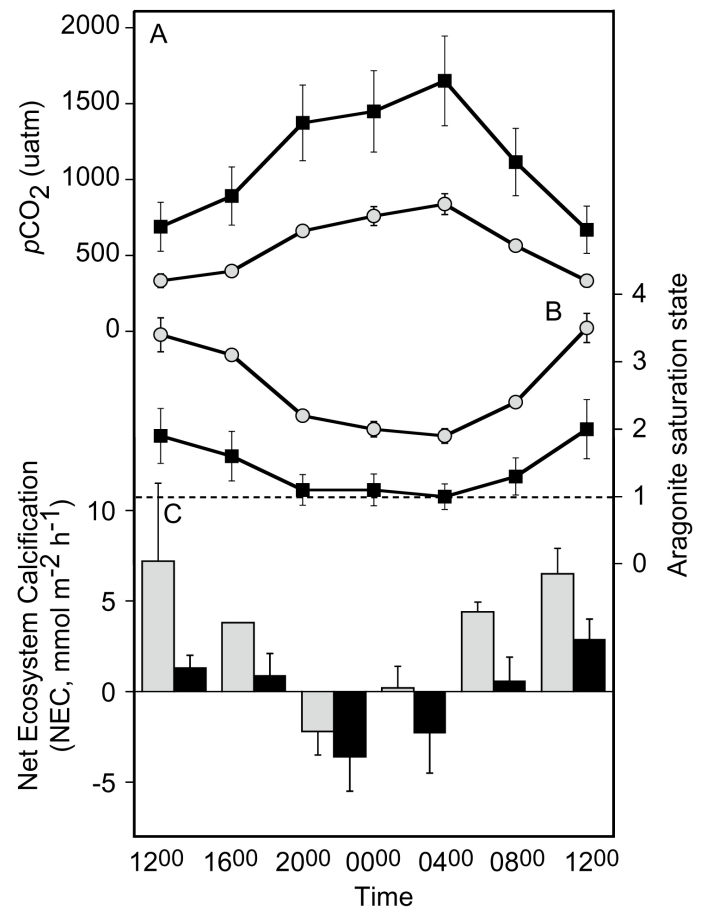

Fig. 4. (A) Seawater partial pressure of $\mathrm{CO}_{2}\left(p \mathrm{CO}_{2}\right)$ and (B), saturation state with respect to aragonite $\left(\Omega_{\text {aragonite }}\right)$ in the control (gray) and treatment (black) mesocosms as a function of time. The dashed line represents seawater equilibrium with respect to aragonite $(\Omega=1)$. (C) NEC in the control and treatment mesocosms during a complete diel cycle under the chemical conditions shown in (A) and (B). Positive values imply net calcification and negative values imply net dissolution. Error bars denote 1 standard deviation $(n=3)$. 
Table 1. Average physical and chemical properties in control ( $n=3$; white rows) and treatment mesocosms ( $n=3$; gray rows) and results of statistical tests. Numbers in parenthesis represent 1 standard deviation. $\Delta$ is the average 24 h difference between control and treatment mesocosms relative to the former.

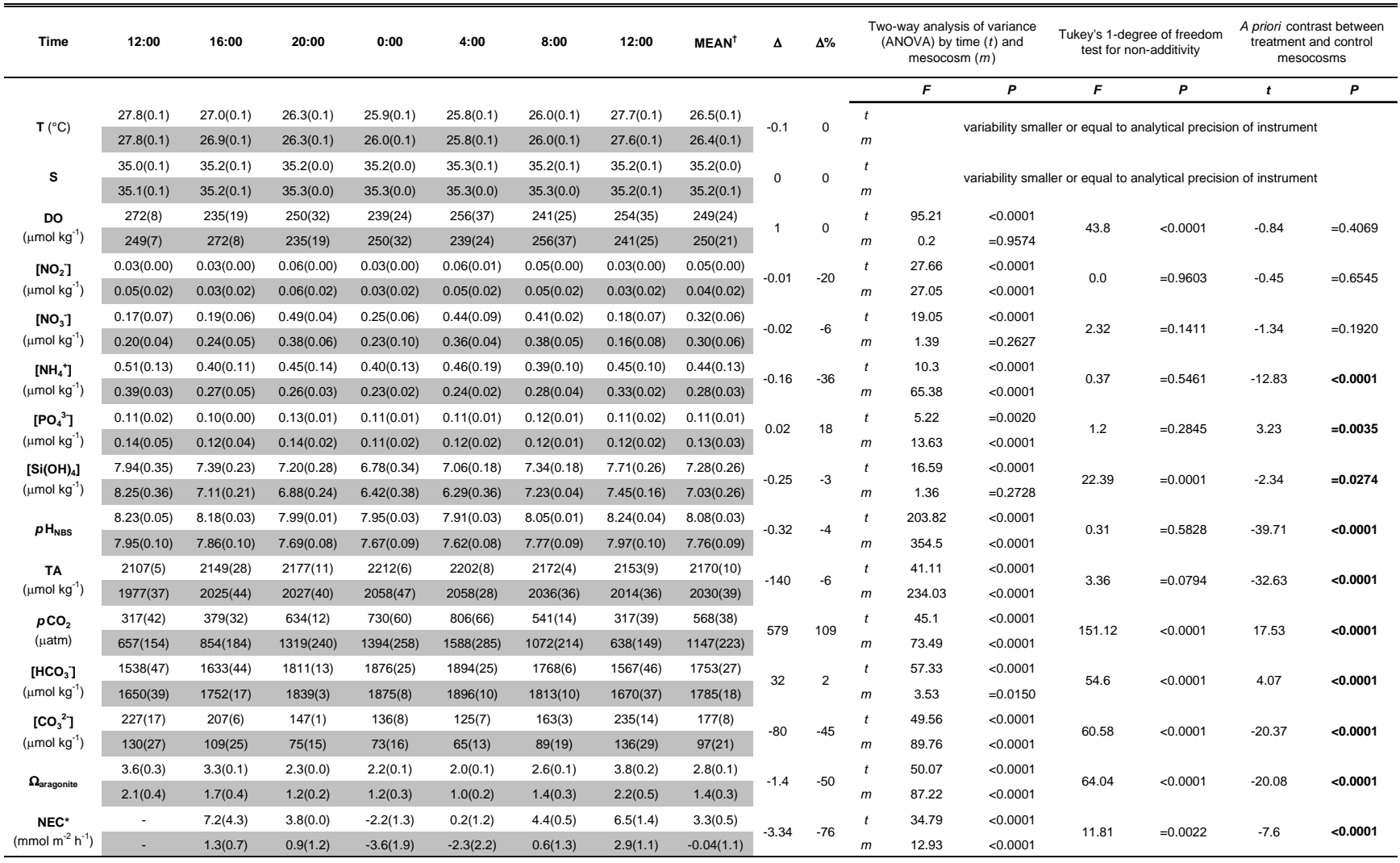

$\dagger$ Mean calculated based on data from 12:00 to 08:00;

* Rank transformation applied to data to meet assumptions of ANOVA.

\subsection{Environmental parameters and nutrient concentra- tions}

Daily average temperature, salinity and dissolved oxygen were close to identical in all mesocosms (Table 1). Nitrate and nitrite concentrations were statistically not different between treatment and control mesocosms, but concentrations of ammonium, phosphate and silicate were significantly different based on two-way ANOVA and a priori contrasts (Table 1). It is not clear whether the observed differences in these cases were due to the seawater acidification treatment or to other factors that were not accounted for. For example, average ammonium concentration was higher in the control relative to the treatment mesocosms. This was possibly due to nitrogen fixation by extensive mats of cyanobacteria observed on the mesocosm walls in two of the three control mesocosms at the time of the diel experiment. These mats reoccurred throughout the long-term experiment, and were observed in both control and treatment mesocosms with no obvious distinguishable pattern in their dynamics. Increases in ammonium concentration during incubations containing cyanobacteria have been observed and reported in other incubation studies (Kuffner and Paul, 2001). The reasons for the statistically significant differences in phosphate (higher in treatment mesocosms) and silicate concentrations (higher in control mesocosms) are unknown. Nevertheless, because the observed differences between treatment and control mesocosms are small $\left(\Delta\left[\mathrm{NH}_{4}^{+}\right] \sim 0.16 \mu \mathrm{mol} \mathrm{kg}^{-1} ; \quad \Delta\left[\mathrm{PO}_{4}^{3-}\right] \sim 0.02 \mu \mathrm{mol} \mathrm{kg}^{-1}\right.$; $\left.\Delta\left[\mathrm{Si}(\mathrm{OH})_{4}\right] \sim 0.25 \mu \mathrm{mol} \mathrm{kg}^{-1}\right)$ and the diel variability low $\left(\Delta_{\text {diel }}\left[\mathrm{NH}_{4}^{+}\right] \sim 0.12-0.16 \mu \mathrm{mol} \mathrm{kg}{ }^{-1} ; \quad \Delta_{\text {diel }}\left[\mathrm{PO}_{4}^{3-}\right] \sim 0.02-\right.$ $\left.0.03 \mu \mathrm{mol} \mathrm{kg}^{-1} ; \quad \Delta_{\text {diel }}\left[\mathrm{Si}(\mathrm{OH})_{4}\right] \sim 1-2 \mu \mathrm{mol} \mathrm{kg}^{-1}\right) \quad$ relative to the observed changes in TA $\left(\Delta_{\text {diel }}[\mathrm{TA}] \sim 80\right.$ $105 \mu \mathrm{mol} \mathrm{kg}^{-1}$; Table 1 and S1), these differences had no major direct or indirect effect on the observed TA and NEC calculations. 


\subsection{Net ecosystem calcification}

The calculated NEC in control mesocosms consistently exceeded NEC in treatment mesocosms and the difference was statistically different (Table 1). Net calcification, i.e., net accumulation of $\mathrm{CaCO}_{3}$, was observed in both treatment and control mesocosms during daytime hours (Fig. 1). The highest average daytime rate $( \pm 1$ std) of calcification was $7.2 \pm 4.3 \mathrm{mmol} \mathrm{m}^{-2} \mathrm{~h}^{-1}$ in the control mesocosms and $2.9 \pm 1.1 \mathrm{mmol} \mathrm{m}^{-2} \mathrm{~h}^{-1}$ in the treatment mesocosms. Net dissolution, i.e., net loss of $\mathrm{CaCO}_{3}$, was observed in both control and treatment mesocosms during nighttime. The highest dissolution rate $( \pm 1 \mathrm{std})$ was $-2.2 \pm 1.3 \mathrm{mmol} \mathrm{m}^{-2} \mathrm{~h}^{-1}$ in the control mesocosms and $-3.6 \pm 1.9 \mathrm{mmol} \mathrm{m}^{-2} \mathrm{~h}^{-1}$ in the treatment mesocosms. Marginal positive calcification was observed during one measurement interval at night (00:00-04:00) in the control mesocosms. Daily average NEC and $\mathrm{CaCO}_{3}$ accumulation were equal to $3.3 \pm 0.5 \mathrm{mmol} \mathrm{CaCO}_{3} \mathrm{~m}^{-2} \mathrm{~h}^{-1}$ or $7.9 \mathrm{~g} \mathrm{CaCO}_{3} \mathrm{~m}^{-2} \mathrm{day}^{-1}$ in the control mesocosms. In contrast, daily average dissolution exceeded calcification in the treatment mesocosms and gave rise to a loss of $-0.04 \pm 1.1 \mathrm{mmol} \mathrm{m}^{-2} \mathrm{~h}^{-1}$ or $-0.1 \mathrm{~g} \mathrm{CaCO}_{3} \mathrm{~m}^{-2} \mathrm{day}^{-1}$. These results are the net of living community metabolism as well as carbonate dissolution occurring in the thin sediment layer that accumulated at the bottom of the mesocosms.

The NEC was correlated to the seawater $\left[\mathrm{CO}_{3}^{2-}\right]$ and aragonite saturation state in both treatment and control mesocosms (Fig. 5). The slope of a best fit line of all the data from the control mesocoms was equal to $4.5 \mathrm{mmol} \mathrm{m}^{-2} \mathrm{~h}^{-1}$ per unit change in aragonite saturation state $\left(r^{2}=0.61\right)$ and the line intercepted $\mathrm{NEC}=0$ at an aragonite saturation state of 1.94. The slope of the best fit line to all the data from the treatment mesocosms was not as steep as that of the control mesocosms and equaled $2.9 \mathrm{mmol} \mathrm{m}^{-2} \mathrm{~h}^{-1}$ per unit change in aragonite saturation state $\left(r^{2}=0.31\right)$. This line intercepted $\mathrm{NEC}=0$ at an aragonite saturation state of 1.46. There was significant variability of the slopes of the best fit lines between replicate mesocosms within both the treatment and the control groups. The slopes varied from 2.4 to $5.7 \mathrm{mmol} \mathrm{m}^{-2} \mathrm{~h}^{-1}\left(r^{2}=0.36-0.71\right)$ per unit change in aragonite saturation state and 3.7 to $5.4 \mathrm{mmol} \mathrm{m}^{-2} \mathrm{~h}^{-1}\left(r^{2}=0.47-\right.$ $0.67)$ per unit change in aragonite saturation state in the individual control and treatment mesocosms, respectively. The aragonite saturation state at which the best fit lines intercepted NEC $=0$ varied between 1.51 to 2.06 and 0.98 to 1.82 in the control and treatment mesocosms, respectively. A best fit line to the combined data from both treatment and control mesocosms had a slope of $3.3 \mathrm{mmol} \mathrm{m}^{-2} \mathrm{~h}^{-1}$ $\left(r^{2}=0.59\right)$ per unit change in aragonite saturation state and intercepted NEC $=0$ at an aragonite saturation state of 1.57 . This intercept corresponds to seawater conditions close to a metastable equilibrium with a $\mathrm{Mg}$-calcite phase containing $10 \mathrm{~mol} \% \mathrm{MgCO}_{3}$ based on experimental solubilities derived by Plummer and Mackenzie (1974). Should these solubil-

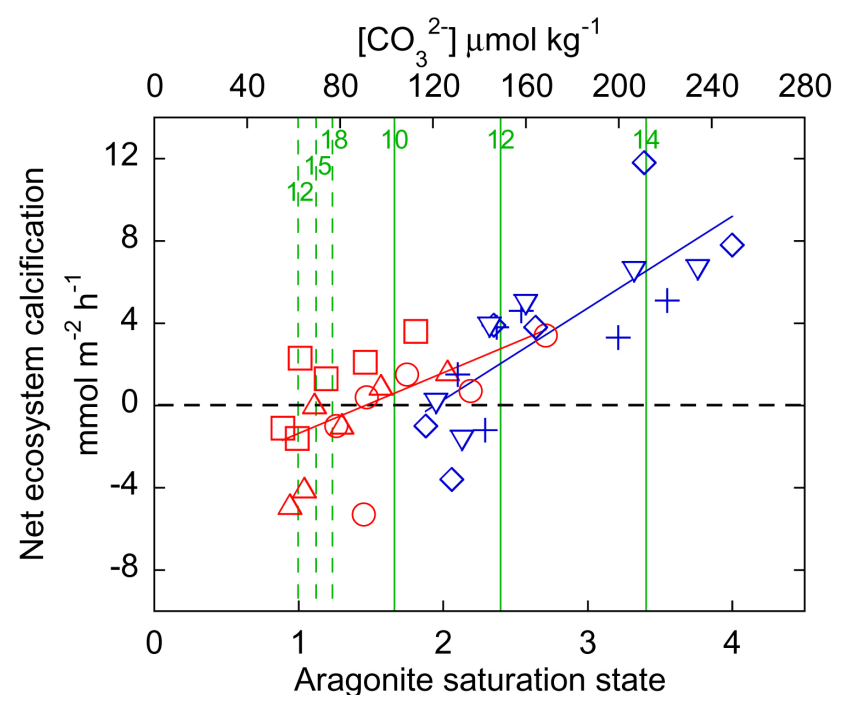

Fig. 5. Net ecosystem calcification in treatment (red symbols; mesocosms: 7, 9, 11) and control (blue symbols; mesocosms: $8,10,12)$ mesocosms as a function of aragonite saturation state (bottom axis) and carbonate ion concentration (top axis). The red and blue lines are the best fit lines to the data in treatment $\left(y=-4.3+2.9 \Omega_{\text {arag }}, r^{2}=0.3 ; y=-4.3+0.047\left[\mathrm{CO}_{3}^{2-}\right], r^{2}=0.3\right)$ and control $\left(y=-8.7+4.5 \Omega_{\mathrm{arag}}, r^{2}=0.6 ; y=-8.9+0.073\left[\mathrm{CO}_{3}^{2-}\right]\right.$, $\left.r^{2}=0.6\right)$ mesocosms, respectively. The vertical green lines and associated numbers represent the $\mathrm{Mg}$-calcite phase in metastable equilibrium with the seawater at a given $\left[\mathrm{CO}_{3}^{2-}\right]$ based on experimental solubilities of Bischoff et al. (1987, 1993; dashed green lines: 12, 15, $18 \mathrm{~mol} \% \mathrm{Mg}$-calcite) and Plummer and Mackenzie (1974; solid green lines: $10,12,14 \mathrm{~mol} \% \mathrm{Mg}$-calcite). At this time, it is not known what solubilities best represent the behavior of Mg-calcite minerals in a natural marine system (e.g., Morse et al., 2006; Andersson et al., 2008).

ities hold true in the present mesocosm setting, this implies that the seawater would be undersaturated with respect to any $\mathrm{Mg}$-calcite phase composition containing $10 \mathrm{~mol} \%$ or more $\mathrm{MgCO}_{3}$ and potentially subject to dissolution at this saturation condition. In contrast, experimental solubilities derived by Bischoff et al. $(1987,1993)$ suggest that seawater is still supersaturated with respect to a $\mathrm{Mg}$-calcite phase containing greater than $18 \mathrm{~mol} \% \mathrm{MgCO}_{3}$ at this saturation state (Fig. 5).

\section{Discussion}

The observed diel trend and difference in NEC between control and treatment mesocosms of the present investigation agree with expectations based on theory and results from previous investigations (e.g., Kayanne et al., 1995; Bates, 2002; Langdon et al., 2000; Leclercq et al., 2002; Langdon and Atkinson, 2005; Yates and Halley, 2006; Silverman et al., 2007). The diel trend in NEC results from a combination of changes in seawater $\mathrm{CO}_{2}$ chemistry and community 
metabolism coupled to changes in the light and dark cycle on this time scale. During daytime, community primary production consumes $\mathrm{CO}_{2}$ at a greater rate than community respiration produces it. This raises the seawater saturation state with respect to carbonate minerals and consequently favors more rapid calcification (Fig 1.; Gattuso et al., 1999; Marubini et al., 2003; Langdon and Atkinson, 2005). In addition, under light conditions, photosynthesizing symbiotic algae provide their coral hosts with substantial amounts of energy that can be utilized for mechanisms such as the calcium-ATPase pump to control the chemistry of their internal calcifying fluid and thus enhance calcification (e.g., Cohen and McConnaughey, 2003). It has been demonstrated that corals calcify 3-5 times faster in light compared to dark conditions, which attests to the important coupling of this process to photosynthesis in these organisms (Gattuso et al., 1999; Schneider and Erez, 2006). At night, in the absence of light and photosynthesis, production of $\mathrm{CO}_{2}$ from respiration lowers seawater saturation state with respect to carbonate minerals. Consequently, calcification is slower and dissolution rates may increase owing to increasingly undersaturated conditions with respect to carbonate minerals in microenvironments and in the water column (Fig. 1). For the same reasons, NEC is anticipated to decrease in response to rising $p \mathrm{CO}_{2}$ and decreasing seawater carbonate saturation state arising from human activities. Indeed, the present results demonstrate lower NEC under elevated $p \mathrm{CO}_{2}$ conditions in treatment mesocosms compared to NEC under ambient conditions in control mesocosms (Fig. 1).

\subsection{Calcification-dissolution budget in mesocosms}

In the long-term companion study (Jokiel et al., 2008), coral growth rates were determined at regular intervals using the buoyant weight technique. If we assume that the daily rate of calcification remained relatively constant during these intervals, this allows us to calculate daily calcification rates owing to coral calcification in each mesocosm. Consequently, combining these data with the NEC data provides us an opportunity to approximate the balance between calcification and dissolution in each mesocosm. Longer-term measurements (14 to 21 days) of coral calcification rates during the months of June and July revealed that the average rate of calcification ( $\pm 1 \mathrm{std})$ attributed to corals equaled $3.9 \pm 0.4 \mathrm{mmol} \mathrm{m}^{-2} \mathrm{~h}^{-1}$ or $9.4 \pm 0.8$ grams $^{-2}$ day $^{-1}$ in the control mesocosms and $3.4 \pm 0.4 \mathrm{mmol} \mathrm{m}^{-2} \mathrm{~h}^{-1}$ or $8.1 \pm 1.1$ grams m$^{-2}$ day $^{-1}$ in the treatment mesocosms during this time period (Jokiel et al., 2008).

Thus, if corals were the only calcifiers in the mesocosms, carbonate mineral dissolution equaled $0.6 \mathrm{mmol} \mathrm{m}^{-2} \mathrm{~h}^{-1}$ and $3.44 \mathrm{mmol} \mathrm{m}^{-2} \mathrm{~h}^{-1}$ in the control and treatment mesocosms, respectively, in order to balance the observed NEC (Fig. 6). In reality, in addition to the 40 colonies of corals in each mesocosm, many other calcifiers were present and contributed to the total ecosystem calcification (see Methods

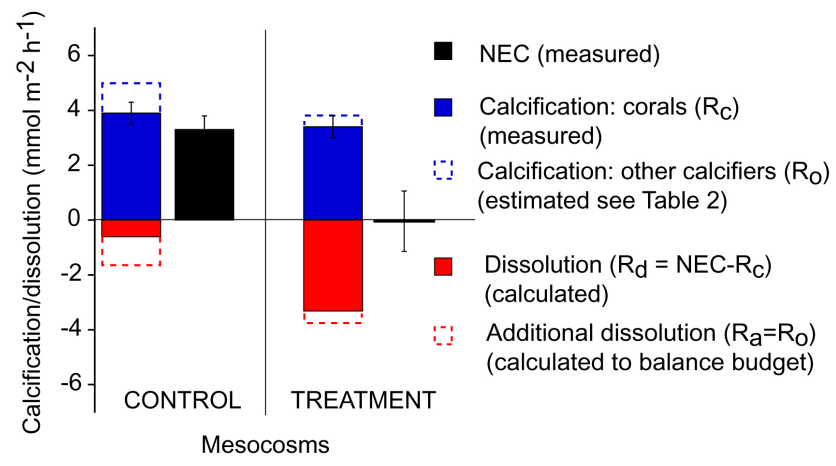

Fig. 6. Calcification (blue bars), dissolution (red bars) and net ecosystem calcification (NEC; black bars) in treatment and control mesocosms. Solid blue part of calcification bars represent calcification by corals determined from the buoyant weight technique $\left(R_{C}\right)$; the dashed blue part represent estimated calcification by other calcifiers according to procedure outlined in Table $2\left(R_{O}\right)$; solid part of red bars represent dissolution calculated from the difference between observed NEC and coral calcification; dashed part of red bars represent additional dissolution required in order to balance the complete budget. The dashed part of each bar also represents increasing uncertainty relative to the solid part of each bar. Error bars represents 1 standard deviation.

section). The exact contribution from the different calcifiers is difficult to ascertain. However, based on their surface area coverage and abundance on the mesocosm walls at the end of the long-term experiment (31 October 2005 to 8 August 2006; Jokiel et al., 2008), and the fact that the mesocosms were completely bare at the onset of this experiment, a rough estimate of their contribution to the NEC can be calculated based on these data and a few assumptions. In this case we assumed that coral settlements, vermetids, and barnacles had the same height as their measured diameter, the thickness of crustose coralline algae and the total shell thickness of oysters equaled $0.5 \mathrm{~mm}$ and $1 \mathrm{~mm}$, respectively (Table 2). Combining these assumptions with the measured surface area, total volume and total mass of $\mathrm{CaCO}_{3}$ were calculated assuming that the estimated volume was comprised of $100 \%$ aragonite or calcite. The rate of calcification was calculated by dividing the total mass of $\mathrm{CaCO}_{3}$ by the total number of days of the long-term experiment ( $280 \mathrm{~d}$ ) normalized per $\mathrm{m}^{2}$ water column. According to this analysis, crustose coralline algae and oysters were by far the most important contributors to the total ecosystem calcification following corals in both control and treatment mesocosms. Calcification by rhodoliths, barnacles, vermetids and coral settlements was negligible. The average total contribution from other calcifiers to the NEC was $1.0 \mathrm{mmol} \mathrm{m}^{-2} \mathrm{~h}^{-1}$ and $0.3 \mathrm{mmol} \mathrm{m}^{-2} \mathrm{~h}^{-1}$ in the control and treatment mesocosms, respectively (Table 2 ). Combined with coral calcification, the total calcification in control and treatment mesocosms was $4.9 \mathrm{mmol} \mathrm{m}^{-2} \mathrm{~h}^{-1}$ and $3.7 \mathrm{mmol} \mathrm{m}^{-2} \mathrm{~h}^{-1}$, respectively. Consequently, in order to balance the calcification/dissolution budget, i.e., 
Table 2. Estimated contribution to total calcification by calcifiers other than adult coral colonies in control and treatment mesocosms.

\begin{tabular}{|c|c|c|c|c|c|c|c|}
\hline \multirow[b]{2}{*}{ Organisms/calcifiers } & \multirow[b]{2}{*}{ *no. $\mathrm{m}^{-2}$} & \multirow[b]{2}{*}{$\begin{array}{c}\text { *Surface } \\
\text { area } \%\end{array}$} & \multirow[b]{2}{*}{$\begin{array}{l}* \text { Surface } \\
\text { area } \mathrm{cm}^{2}\end{array}$} & \multirow[b]{2}{*}{$\begin{array}{c}\text { *Volume } \\
\mathrm{CaCO}_{3} \\
\mathrm{~cm}^{3}\end{array}$} & \multirow[b]{2}{*}{$\begin{array}{c}\star^{\dagger} \mathrm{Mass} \\
\mathrm{CaCO}_{3} \\
\text { gram }\end{array}$} & \multicolumn{2}{|c|}{ Calcification rate: } \\
\hline & & & & & & $\begin{array}{l}{ }^{ \pm} \text {gram } \\
\mathrm{m}^{-2} \mathrm{~d}^{-1}\end{array}$ & $\begin{array}{l}{ }^{ \pm} \mathrm{mmol} \\
\mathrm{m}^{-2} \mathrm{~h}^{-1}\end{array}$ \\
\hline \multicolumn{8}{|l|}{ CONTROL MESOCOSMS } \\
\hline Rhodoliths & 4 & - & - & - & 41.3 & 0.001 & 0.001 \\
\hline${ }^{1}$ Coral settlements $(\varnothing=2.5 \mathrm{~mm})$ & 55 & - & 2.7 & 0.7 & 2.0 & 0.01 & 0.002 \\
\hline${ }^{1}$ Vermetids (ø 5mm) & 78.4 & - & 15.4 & 7.7 & 20.9 & 0.05 & 0.02 \\
\hline${ }^{1}$ Barnacles $(\varnothing \sim 5.1 \mathrm{~mm})$ & 8.3 & - & 1.7 & 0.9 & 2.3 & 0.01 & 0.003 \\
\hline${ }^{2}$ Crustose coralline algae & - & 25 & 4680.0 & 234.0 & 634.1 & 1.7 & 0.7 \\
\hline${ }^{3}$ Oysters & - & 5.7 & 1067.0 & 106.7 & 289.2 & 0.8 & 0.3 \\
\hline Turf algae & - & 16.6 & 3107.5 & 0 & 0 & 0 & 0 \\
\hline Bare substratum & - & 53.2 & 9959.0 & 0 & 0 & 0 & 0 \\
\hline Total & & & 18833.4 & 349.9 & 989.8 & 2.5 & 1.0 \\
\hline \multicolumn{8}{|l|}{ TREATMENT MESOCOSMS } \\
\hline Rhodoliths & 4 & - & - & - & 35.1 & -0.002 & -0.001 \\
\hline${ }^{1}$ Coral settlements $(\varnothing=2.8 \mathrm{~mm})$ & 49 & - & 3.0 & 0.8 & 2.5 & 0.01 & 0.003 \\
\hline${ }^{1}$ Vermetids ( $\left.\varnothing \sim 5 \mathrm{~mm}\right)$ & 7.7 & - & 1.5 & 0.8 & 2.0 & 0.01 & 0.002 \\
\hline${ }^{1}$ Barnacles $(\varnothing \sim 6.0 \mathrm{~mm})$ & 4.5 & - & 1.3 & 0.8 & 2.1 & 0.01 & 0.002 \\
\hline${ }^{2}$ Crustose coralline algae & - & 3.6 & 673.9 & 33.7 & 91.3 & 0.2 & 0.1 \\
\hline${ }^{3}$ Oysters & - & 4.4 & 823.7 & 82.4 & 223.2 & 0.6 & 0.2 \\
\hline Turf algae & - & 14.5 & 2714.4 & 0 & 0 & 0 & 0 \\
\hline Bare substratum & - & 77.5 & 14508.0 & 0 & 0 & 0 & 0 \\
\hline Total & & & 18725.8 & 118.4 & 356.2 & 0.8 & 0.3 \\
\hline
\end{tabular}

1 Assuming same height as diameter;

2 Assuming $0.5 \mathrm{~mm}$ thickness;

3 Assuming $1 \mathrm{~mm}$ total shell thickness;

* On mesocosm walls;

$\dagger$ Assuming calculated volume is $100 \%$ aragonite $\left(\rho=2.93 \mathrm{~g} \mathrm{~cm}^{-3}\right)$ or calcite $\left(\rho=2.71 \mathrm{~g} \mathrm{~cm}^{-3}\right)$;

$\ddagger$ Per $\mathrm{m}^{2}$ water column.

NEC, the estimated average rate of total dissolution equaled $1.6 \mathrm{mmol} \mathrm{m}^{-2} \mathrm{~h}^{-1}$ and $3.74 \mathrm{mmol} \mathrm{m}^{-2} \mathrm{~h}^{-1}$ in the control and treatment mesocosms, respectively (Fig. 6).

The results of this analysis suggest that the observed difference in NEC between ambient and elevated $p \mathrm{CO}_{2}$ conditions in the present study was due to: 1) marginally slower calcification in corals $(-13 \%) ; 2)$ a smaller contribution to the total calcification from other calcifiers $(-70 \%)$ owing to lower abundances arising from reduced recruitment over the long-term experiment and most likely also slower calcification (Jokiel et al., 2008; Kuffner et al., 2008); and 3), a faster and greater extent of carbonate dissolution $(+134 \%)$ under elevated $p \mathrm{CO}_{2}$ conditions (Fig. 6).

\subsubsection{Calcification: corals}

In agreement with previous studies, corals exposed to elevated $p \mathrm{CO}_{2}$ and lower $\Omega_{\text {aragonite }}$ conditions calcified slower compared to corals exposed to ambient conditions in the present investigation. Buoyant weight measurements conducted during the months of June and July suggested a decrease in calcification of approximately $13 \%$ compared to a decrease of $15 \%$ to $20 \%$ observed in the long-term experiment and repeated weight measurements throughout the 10 month duration of the experiment (Jokiel et al., 2008). The results and the response of corals in other investigations vary significantly with a decrease in calcification ranging from 0 to $-56 \%$ owing to a doubling of $p \mathrm{CO}_{2}$ (see Table 1.1 Kleypas et al., 2006; e.g., Marubini et al., 2003; Langdon and Atkinson, 2005; Schneider and Erez, 2006). This large variability in the response of corals to elevated $p \mathrm{CO}_{2}$ conditions likely reflects complex interactions of a number of factors including the influence of additional environmental parameters (e.g., light, temperature, nutrient concentration, hydrologic regime), coral host-symbiont interactions and activity, life history, species specific responses, as well as different experimental settings. In the present investigation, it is important to recognize that despite the very high seawater $p \mathrm{CO}_{2}$ (d.a. $p \mathrm{CO}_{2} \sim 1147 \mu \mathrm{atm}$ ) and low aragonite saturation state (d.a. $\Omega_{\text {aragonite }} \sim 1.4$ ) prevalent in the treatment mesocosms, and the fact that these mesocosms were subject to net dissolution, individual coral colonies remained healthy, actively calcified, and deposited significant amounts of $\mathrm{CaCO}_{3}$ 
under these conditions. Coral calcification rates in treatment mesocosms were only marginally reduced compared to calcification rates observed in control mesocosms.

\subsubsection{Calcification: other organisms}

Based on the results from the long-term experiment of the present mesocosm investigation, some other calcifiers appeared drastically negatively affected by the prevailing high seawater $p \mathrm{CO}_{2}$ and low $\Omega_{\text {aragonite }}$ treatment conditions whereas others did not appear affected at all (Jokiel et al., 2008). For example, physical dissolution was observed in Mg-calcite rhodoliths that lost mass throughout the long-term experiment in the treatment mesocosms (Jokiel et al., 2008). Similarly, recruitment of crustose coralline algae (CCA) depositing Mg-calcite containing 13-14 mol\% $\mathrm{MgCO}_{3}$ was significantly reduced by as much as $85 \%$ under treatment conditions (Jokiel et al., 2008; Kuffner et al., 2008). Interestingly, both rhodoliths and CCA deposit calcium carbonate minerals containing significant proportions magnesium, i.e., high Mg-calcite. Considering that the treatment mesocosms were at times undersaturated with respect to all $\mathrm{Mg}$-calcite minerals more soluble than aragonite, it is not surprising that these organisms were negatively affected since they were potentially subject to dissolution at these times. In contrast, there was no significant difference in the percent cover of oysters and the number of barnacles on the walls of treatment and control mesocosms (Jokiel et al., 2008). Oysters commonly deposit Mg-calcite containing a few $\mathrm{mol} \% \mathrm{MgCO}_{3}$ (low $\mathrm{Mg}$-calcite) or aragonite and the seawater remained supersaturated with respect to these mineral phases. Barnacles commonly deposit high $\mathrm{Mg}$-calcite, but in terms of their abundance, they appeared little affected by the treatment seawater conditions. However, it is possible that other properties of these organisms could have been negatively impacted that were not measured. For example, a recent study investigating the effect of ocean acidification on barnacles ( $\mathrm{pH}_{\mathrm{NBS}}$ of 7.4 vs. 8.2) observed no negative effect on larval and adult growth and development, but observed a $33 \%$ reduction in juvenile settlement and also weaker strength of adult's shell walls (McDonald et al., 2009). Other investigators have demonstrated reduced growth and calcification rates in organisms depositing high $\mathrm{Mg}$-calcite such as coralline algae exposed to elevated $p \mathrm{CO}_{2}$ conditions (e.g., Agegian, 1985; Smith and Roth, 1979; Gao et al., 1993; Anthony et al., 2008; Martin and Gattuso, 2009). Similar responses have also been observed in oysters (Gazeau et al., 2007).

\subsubsection{Carbonate dissolution}

Carbonate dissolution is an ongoing process in all coral reef environments resulting from the metabolic activity of microbes generating corrosive conditions in microenvironments and sediment pore waters, as well as endolithic microor- ganisms actively colonizing and penetrating carbonate substrates (Alexandersson, 1975b; Tribollet, 2008; Tribollet et al., 2009). Consequently, a decrease in seawater saturation state with respect to carbonate minerals due to rising $p \mathrm{CO}_{2}$ will result in increasingly corrosive conditions with respect to these mineral phases and subsequently increased rates of dissolution. Thus, it is not surprising that the estimated rates of dissolution in treatment mesocosms exceeded the rates of dissolution in control mesocosms. Because Mg-calcite minerals with a significant $\mathrm{mol} \% \mathrm{Mg}$ are more soluble than both aragonite and calcite, these mineral phases are likely to be the first responders to increasing $\mathrm{CO}_{2}$ conditions (Morse et al., 2006). This was evident by the loss of mass in Mg-calcite rhodoliths in treatment mesocosms. However, most of the dissolution most likely occurred in the thin sediment layer present on the bottom of the tanks. This layer accumulated throughout the long-term experiment as a result of physical and biological dissolution and disintegration processes inside the mesocosms as well as deposition of small particles transported via the seawater intake lines. This material was very fine-grained and thus had a high specific surface area making it susceptible to dissolution. Regrettably, no mineral composition or grain size analysis were conducted on this material, but mineral analysis of surface sediments throughout Kaneohe Bay showed an average $\mathrm{Mg}$-calcite composition of $13-15 \mathrm{~mol} \% \mathrm{MgCO}_{3}$ constituting $\sim 40 \%$ of the total carbonate reservoir compared to $\sim 50 \%$ aragonite and $\sim 10 \%$ calcite (Andersson, unpublished data). Furthermore, as seawater aragonite saturation states in treatment mesocosms at times were close to equilibrium, it is likely microenvironments in the sediment layer were undersaturated with respect to this mineral phase and potentially subject to dissolution.

Estimates of carbonate dissolution from a range of different tropical and subtropical environments range from 0.1$7 \mathrm{mmol} \mathrm{m}^{-2} \mathrm{~h}^{-1}$ (see Table 3 in Andersson et al., 2007; e.g., Kinsey, 1978; Langdon et al., 2000; Yates and Halley, 2006). Thus, the present estimates of $1.6 \mathrm{mmol} \mathrm{m}^{-2} \mathrm{~h}^{-1}$ and $3.74 \mathrm{mmol} \mathrm{m}^{-2} \mathrm{~h}^{-1}$ in the control and treatment mesocosms, respectively, fall within this range. In general, dissolution rates increase with increasing seawater $p \mathrm{CO}_{2}$ and decreasing carbonate saturation state within a specific experiment, but dissolution rates vary significantly between different experiments and environments. It has also been demonstrated that the extent of dissolution owing to euendolithic microorganisms increases under elevated seawater $\mathrm{CO}_{2}$ conditions (Tribollet et al., 2009). Similar to the effect of elevated $\mathrm{CO}_{2}$ on coral calcification, the extent and rate of carbonate dissolution are affected by many parameters in addition to seawater $\mathrm{CO}_{2}$ chemistry including microbial activity, organic matter content and reactivity, hydrologic regime, sediment grain size and surface area, and sediment composition (e.g., average $\mathrm{mol} \% \mathrm{Mg}$-calcite composition and content). 


\subsection{NEC in different coral reef communities and $p \mathrm{CO}_{2}$ conditions}

The observed daily NEC in control $\left(7.9 \mathrm{~g} \mathrm{CaCO}_{3} \mathrm{~m}^{-2}\right.$ $\left.\mathrm{day}^{-1}\right)$ and treatment $\left(-0.1 \mathrm{~g} \mathrm{CaCO}_{3} \mathrm{~m}^{-2} \mathrm{day}^{-1}\right)$ mesocosms of the present investigation falls within the range of results achieved for a number of different studies investigating community calcification either in situ or in mesocosms for a range of different coral reef communities, substratum types, $\mathrm{CO}_{2}$ conditions and different approaches used to calculate NEC. The daily average net community calcification rates in these studies range from $-1 \mathrm{~g} \mathrm{CaCO}_{3} \mathrm{~m}^{-2} \mathrm{day}^{-1}$ to $25 \mathrm{~g} \mathrm{CaCO}_{3} \mathrm{~m}^{-2}$ day $^{-1}$ (e.g., Gattuso et al., 1996; Boucher et al., 1998; Langdon et al., 2000; Leclercq et al., 2002; Bates, 2002; Yates and Halley, 2006; Silverman et al., 2007). Although most studies are based on the associated decrease or increase in total alkalinity for every mol $\mathrm{CaCO}_{3}$ precipitated or dissolved, respectively (i.e., alkalinity anomaly technique; Smith and Key, 1975; Smith and Kinsey, 1978), the duration of these investigations range from short term experiments $(\sim 1-3 \mathrm{~h})$ under light and dark conditions extrapolated to a daily cycle (Gattuso et al., 1996; Boucher et al., 1998; Leclercq et al., 2002) to discrete measurements every $3-4 \mathrm{~h}$ over complete diel cycles (24-48 h; Yates and Halley, 2006; Silverman et al., 2007), and even longer time periods (Langdon et al., 2000). Because of the large differences in experimental settings and conditions, it is not informative to make direct comparisons of results between all these studies and the present investigation. Focusing on studies of similar duration to the present investigation, Yates and Halley (2006) reported daily community calcification rates on patch reefs on the Molokai reef flat, Hawaii, based on incubations using the SHARQ chamber of $-0.7 \mathrm{~g} \mathrm{CaCO}_{3} \mathrm{~m}^{-2}$ day $^{-1}$ $\left(10 \%\right.$ coral cover; d.a. $p \mathrm{CO}_{2} \sim 500 \mu \mathrm{atm}$; d.a. $\left.\Omega_{\text {aragonite }} \sim 2.8\right), \quad 0.4 \mathrm{~g} \mathrm{CaCO}_{3} \mathrm{~m}^{-2}$ day $^{-1} \quad(10 \%$ coral cover; d.a. $\quad p \mathrm{CO}_{2} \sim 930 \mu \mathrm{atm} ; \quad$ d.a. $\Omega_{\text {aragonite }} \sim 1.9$ ), and $0.3 \mathrm{~g} \mathrm{CaCO}_{3} \mathrm{~m}^{-2}$ day $^{-1}(22 \%$ coral cover; d.a. $p \mathrm{CO}_{2} \sim 590 \mu \mathrm{atm}$; d.a. $\Omega_{\text {aragonite }} \sim 2.5$ ). Interestingly, although net community calcification appeared correlated to seawater $p \mathrm{CO}_{2}$ and $\Omega_{\text {aragonite }}$ in each one of these experiments, no apparent trend was obvious as a function of these parameters between experiments. These differences probably highlight the many factors previously discussed that may play a role affecting calcification and dissolution processes, and thus, the net ecosystem calcification. In another study, Silverman et al. (2007) reported daily community calcification rates of $6 \pm 2 \mathrm{~g} \mathrm{CaCO}_{3} \mathrm{~m}^{-2}$ day $^{-1}$ during summer and $3 \pm 2 \mathrm{~g} \mathrm{CaCO}_{3} \mathrm{~m}^{-2}$ day $^{-1}$ during winter from a fringing reef of $20-40 \%$ coral cover in the Gulf of Aqaba, Red Sea. Net community calcification rates were strongly correlated to the natural range of seawater $\Omega_{\text {aragonite }}$ ranging from $\sim 3.7-4.5$. Additional studies investigating the effect of rising levels of $\mathrm{CO}_{2}$ and decreasing $\Omega$ on coral reef community calcification show a consistent decrease in the daily rate of calcification concurrent with changes in these parameters (e.g., Langdon et al., 2000; Leclercq et al., 2002). However, under dark conditions, Leclercq et al. (2002) observed net carbonate dissolution in a mesocosm experiment of a coral community comprised of corals, coralline algae and calcareous sand, but did not observe any correlation between the rate of dissolution and the surface seawater $\Omega_{\text {aragonite }}$. These authors suggested that the carbonate saturation state of the sediment pore-water and the rate of carbonate dissolution were mostly controlled by microbial respiration in the sediments and little affected by the carbonate saturation state of the overlying seawater.

Similar to the present study, Langdon et al. (2000) observed marginal net ecosystem dissolution in their Biosphere 2 experiment at seawater $\Omega_{\text {aragonite ranging from }}$ 1.17-1.35. Amphiroa rigida, a red coralline alga that deposits high $\mathrm{Mg}$-calcite (22 $\mathrm{mol} \% \mathrm{MgCO}_{3}$ in this experiment) was an important component of the Biosphere calcifying community. Based on this study and the results of the present investigation, it may be speculated that the transition of a coral ecosystem from net accumulation of $\mathrm{CaCO}_{3}$ to a state of net dissolution may be significantly dependent on the composition and contribution to the total ecosystem calcification from organisms depositing high Mg-calcite as well as the content and average composition of these mineral phases in the sediments. Since high Mg-calcite mineral phases are more soluble than both calcite and aragonite, these are the first mineral phases that will become subject to dissolution owing to rising $p \mathrm{CO}_{2}$ and decreasing carbonate saturation state (Morse et al., 2006; Andersson et al., 2007). For the same reason, it is likely organisms depositing high $\mathrm{Mg}$ calcite minerals, e.g., coralline algae, will experience severe negative consequences as a result of ocean acidification before organisms such as corals, which deposit aragonite (Andersson et al., 2008).

\subsection{NEC vs. $p \mathrm{CO}_{2}, \mathrm{CO}_{3}^{2-}, \Omega$, and "critical threshold" values}

Although calcification by marine organisms is influenced by many parameters including light, temperature and nutrients, seawater $\left[\mathrm{CO}_{3}^{2-}\right]$ and carbonate saturation state have an apparent strong control on calcification rates of both individual organisms and entire communities (Gattuso et al., 1999; Langdon et al., 2000; Schneider and Erez, 2006; Silverman et al., 2007). Similar to the large variability observed in calcification and dissolution rates as a function of different $\mathrm{CO}_{2}$ conditions, the dependence of calcification and dissolution on $\left[\mathrm{CO}_{3}^{2-}\right]$ and $\Omega$ i.e., the slope and the zero intercept will vary significantly between different organisms and environments. Nevertheless, these empirical relationships are important because they are the only way to realistically parameterize models and conduct future model predictions (e.g., Andersson et al., 2003, 2005; McNeil et al., 2004; Silverman et al., 2009). Some investigators have 
attempted to define a critical threshold value with respect to either $p \mathrm{CO}_{2}$ or $\left[\mathrm{CO}_{3}^{2-}\right]$ when dissolution will equal calcification (i.e., $\mathrm{NEC}=0$ ) in different tropical and subtropical coral reef environments (Yates and Halley, 2006). It is important to realize that such threshold values will vary significantly from environment to environment as a result of a myriad of factors that are difficult to account for accurately and depend on the temporal and spatial scale being considered. For example, Yates and Halley (2006) observed that critical thresholds with respect to $p \mathrm{CO}_{2}$ and $\left[\mathrm{CO}_{3}^{2-}\right]$ ranged from $467-1003 \mu \mathrm{atm}$ and $113-184 \mu \mathrm{mol} \mathrm{kg}^{-1}$, respectively, for several environments including sand bottom, coral rubble and patch reefs of $10-22 \%$ coral cover. In the present study, this threshold occurred at $\left[\mathrm{CO}_{3}^{2-}\right]$ of $61.0-$ $130.0 \mu \mathrm{mol} \mathrm{kg}{ }^{-1}$ based on the relationships derived from individual mesocosms, $91.8 \mu \mathrm{mol} \mathrm{kg}^{-1}$ and $122.9 \mu \mathrm{mol} \mathrm{kg}^{-1}$ based on the relationships derived for treatment and control mesocosms, respectively, and $98.5 \mu \mathrm{mol} \mathrm{kg}{ }^{-1}$ based on the combined dataset (Fig. 5). However, what is important in this context is not the precise threshold value but rather the current trend and the relatively small changes in seawater chemistry required to reverse the net effect of marine calcification and carbonate dissolution. These conditions are expected to become reality within several decades under a business-asusual $\mathrm{CO}_{2}$ emission scenario. Some environments, such as the coral reef of Bermuda $\left(32^{\circ} \mathrm{N}\right)$, may become subject to a net loss in $\mathrm{CaCO}_{3}$ much sooner than ecosystems located at more tropical latitudes because of already lower average seawater $\left[\mathrm{CO}_{3}^{2-}\right]$ and $\Omega$ at higher latitude locations (e.g., Kleypas et al., 1999). A recent model study suggest that all coral reefs will cease to grow and start to dissolve (i.e., $\mathrm{NEC}<=0$ ) at an atmospheric $\mathrm{CO}_{2}$ concentration of $560 \mathrm{ppm}$ owing to reduced rates of calcification and a significant reduction in coral cover as a result of coral bleaching (Silverman et al., 2009). In the absence of the effect of warming and coral bleaching, net ecosystem dissolution in the present investigation became reality at much higher seawater $p \mathrm{CO}_{2}$ conditions than projected in this model. In addition, despite the fact that the mesocosm ecosystem was subject to net dissolution, individual coral colonies remained healthy and actively calcified at this condition. In this context, it is important to make the distinction and to realize that coral reef ecosystems will become subject to a condition of net dissolution before individual coral colonies are likely to experience this condition as a result of rising $p \mathrm{CO}_{2}$ and decreasing seawater carbonate saturation state. However, as is evident from the results of Silverman et al. (2009) and other studies (e.g., Reynaud et al., 2003; Hoegh-Guldberg et al., 2005, 2007; Anthony et al., 2008), additional stressors owing to global warming, coral bleaching, and crown-of-star outbreaks may, combined with ocean acidification, pose exceptional challenging conditions for corals and coral reefs to sustain themselves in a future high $\mathrm{CO}_{2}$ world.

\subsection{Broader scale implications of results}

As previously discussed, the observed difference in NEC between ambient and future seawater conditions is consistent with what we might expect as a result of lower seawater carbonate saturation state, i.e., slower calcification and faster dissolution. However, the fact that the daily average NEC reached negative values under the prevailing chemical conditions of the treatment mesocosms has important implications for the function and role of coral reefs and carbonate environments in the cycling of carbon should these conditions materialize in the natural environment. Since the sea level low stand of the last glacial maximum $(\sim 18000$ years before present) and concurrent with the rise in sea level and the evolution of the present coastal ocean, significant accumulations of biologically produced $\mathrm{CaCO}_{3}$ have occurred throughout shallow-water ocean environments worldwide (Milliman, 1993; Milliman and Droxler, 1996). Thus, the transition from net accumulation of $\mathrm{CaCO}_{3}$ to a net loss represents a major reversal of a process that has been in effect for thousands of years. Interestingly, the transition to negative NEC acts as a weak negative feedback to rising anthropogenic $\mathrm{CO}_{2}$ and ocean acidification since dissolution of calcium carbonate minerals consumes $\mathrm{CO}_{2}$ through the reaction:

$\mathrm{CaCO}_{3}+\mathrm{CO}_{2}+\mathrm{H}_{2} \mathrm{O}=\mathrm{Ca}^{2+}+2 \mathrm{HCO}_{3}^{-}$.

Furthermore, this reaction increases alkalinity which further increases the capacity of the seawater to absorb more $\mathrm{CO}_{2}$. However, this process is slow relative to the rate at which human activities are changing the chemistry of surface seawater and it has been demonstrated that it will not produce sufficient alkalinity to produce a significant buffer effect on time scales of decades to centuries either on a global or a regional spatial scale (e.g., Andersson et al., 2003, 2005).

Based on the current global socio-economic situation, it is highly unlikely that anthropogenic $\mathrm{CO}_{2}$ emissions to the atmosphere will decrease in the next several decades. Regardless of the effect of this additional $\mathrm{CO}_{2}$ accumulating in the atmosphere on the magnitude of change of future global average temperature, which is still debated, the oceans will continue to absorb a significant fraction of this gas causing increased acidity and all the potential ecological consequences associated with this major change in seawater chemistry.

Acknowledgements. We are very grateful for the reviews from Joanie Kleypas and one anonymous reviewer as well as comments provided by Associate Editor Jean-Pierre Gattuso that significantly improved an initial draft of this manuscript. This work was partially supported by NSF (Grants ATM 04-39051, EAR 02-23509, and OCE 07-49401, FTM), USGS Terrestrial, Freshwater and Marine Ecosystem program and the USGS Coastal and Marine Geology program (IBK), EPA Star (R832224-010) and NOAA National Ocean Service (PLJ). Any use of trade, product, or firm names is for descriptive purposes only and does not imply endorsement by the U.S. Government. FTM also gratefully acknowledges 
partial support from a grant from the FNRS of the Belgium-French community.

Edited by: J.-P. Gattuso

\section{References}

Agegian, C. R.: The biogeochemical ecology of Porolithon gardineri (foslie), Ph.D. dissertation, Univ. of Hawaii, Honolulu, 1985.

Alexandersson, E. T.: Etch patterns on calcareous sediment grains: petrographic evidence of marine dissolution of carbonate minerals, Science, 189, 47-48, 1975a.

Alexandersson, E. T.: Marks of unknown carbonate-decomposing organelles in cyanophyte borings, Nature, 254, 212-238, 1975 b.

Andersson, A. J., Bates, N. R., and Mackenzie, F. T.: Dissolution of carbonate sediments under rising $p \mathrm{CO}_{2}$ and ocean acidification: observations from Devil's Hole, Bermuda, Aquat. Geochem., 13, 237-264, 2007.

Andersson, A. J., Mackenzie, F. T., and Ver, L. M.: Solution of shallow-water carbonates: an insignificant buffer against rising atmospheric $\mathrm{CO}_{2}$, Geology, 31, 513-516, 2003.

Andersson, A. J., Mackenzie, F. T., and Lerman, A.: Coastal ocean and carbonate systems in the high $\mathrm{CO}_{2}$ world of the Anthropocene, Am. J. Sci., 305, 875-918, 2005.

Andersson, A. J., Mackenzie, F. T., and Lerman, A.: Coastal ocean $\mathrm{CO}_{2}$-carbonic acid-carbonate sediment system of the Anthropocene, Global Biogeochem. Cy., 20, GB1S92, doi:10.1029/2005GB002506, 2006.

Andersson, A. J., Mackenzie, F. T., and Bates, N. R.: Life on the margin: implications of ocean acidification on $\mathrm{Mg}$-calcite, high latitude and cold-water marine calcifiers, Mar. Ecol. Prog. Ser., 373, 265-273, 2008.

Anthony, K. R. N., Kline, D. I., Diaz-Pulido, G., Dove, S., and Hoegh-Guldberg, O.: Ocean acidification causes bleaching and productivity loss in coral reef builders, P. Natl. Acad. Sci., 105, 17442-17446, 2008.

Bates, N. R.: Seasonal variability of the effect of coral reefs on seawater $\mathrm{CO}_{2}$ and air-sea $\mathrm{CO}_{2}$ exchange, Limnol. Oceanogr., 47, 43-52, 2002.

Boucher, G., Clavier, J., Hily, C., and Gattuso, J.-P.: Contribution of soft-bottoms to the community metabolism (primary production and calcification) of a barrier reef flat (Moorea, French Polynesia), J. Exp. Mar. Biol. Ecol., 225, 269-283, 1998.

Caldeira, K. and Wickett, M. E.: Anthropogenic carbon and ocean pH, Nature, 425, 365-365, 2003.

Cohen, A. L. and McConnaughey, T. A.: Geochemical perspectives on coral mineralization, in: Biomineralization, Reviews in Mineralogy and Geochemistry, vol. 54, edited by: Dove, P. M., De Yoreo, J. J., and Weiner, S., Mineralogical Society of America, 151-187, 2003.

Dickson, A. and Millero, F. J.: A comparison of the equilibrium constants for the dissociation of carbonic acid in seawater media, Deep-Sea Res., 38, 1733-1743, 1987.

DOE: Handbook of Methods for the Analysis of the Various Parameters of the Carbon Dioxide System in Sea Water, v. 2, edites by: Dickson, A. G. and Goyet, C., ORNL/CDIAC-74, 1994.

Frankignoulle, M., Gattuso, J.-P., Biondo, R., Bourge, I., CopinMontégut, and Pichon, M.: Carbon fluxes in coral reefs. II. Eular- ian study of inorganic carbon dynamics and measurement of airsea $\mathrm{CO}_{2}$ exchanges, Mar. Ecol. Prog. Ser., 145, 123-132, 1996.

Gao, K., Aruga, Y., Asada, K., Ishihara, T., Akano, T., and Kiyohara, M.: Calcification in the articulated coralline alga Coralline pilulifera, with special reference to the effect of elevated $\mathrm{CO}_{2}$ concentration, Mar. Biol., 117, 129-132, 1993.

Gattuso, J.-P., Allemand, P. D., and Frankignoulle, M.: Photosynthesis and calcification at cellular, organismal and community levels in coral reefs: a review on interactions and control by carbonate chemistry, Am. Zool., 39, 160-183, 1999.

Gattuso, J.-P., Pichon, M., Delesalle, B., Canon, C., and Frankignoulle, M.: Carbon fluxes in coral reefs. I. Lagrangian measurement of community metabolism and resulting air-sea $\mathrm{CO}_{2}$ disequilibrium, Mar. Ecol. Prog. Ser., 145, 109-121, 1996.

Gazeau, F., Quiblier, C., Jansen, J. M., Gattuso, J.-P., Middelburg, J. J., and Heip, C. H. R.: Impact of elevated $\mathrm{CO}_{2}$ on shellfish calcification, Geophys. Res. Lett., 34, L07603, doi:10.1029/2006GL028554, 2007.

Grasshoff, K., Kremling, K., and Ehrhardt, M. (Eds.): Methods of Seawater Analysis, 2nd ed., Verlag Chemie, Weinheim, Germany, 1983.

Hoegh-Guldberg, O.: Low coral cover in a high- $\mathrm{CO}_{2}$ world, J. Geophys. Res., 110, C09S06, doi:10.1029/2004JC002528, 2005.

Hoegh-Guldberg, O., Mumby, P. J., Hooten, A. J., Steneck, R. S., Greenfield, P., Gomez, E., Harvell, C. D., Sale, P. F., Edwards, A. J., Caldeira, K., Knowlton, N., Eakin, C. M., Iglesias-Prieto, R., Muthiga, N., Bradbury, R. H., Dubi, A., and Hatziolos, M. E.: Coral reefs under rapid climate change and ocean acidification, Science, 318, 1737-1742, 2007.

IPCC: Climate change 2001: The scientific basis, Contribution of Working Group I to the Third Assessment Report of the Intergovernmental Panel on Climate Change, edited by: Houghton, J. T., Ding, Y., Griggs, D. J., Noguer, M., van der Linden, P. J., Dai, X., Maskell, K., and Johnson, C. A., Cambridge University Press, Cambridge, United Kingdom and New York, NY, USA.

Jokiel, P. L., Rodgers, K. S., Kuffner, I. B., Andersson, A. J., Cox, E. F., and Mackenzie, F. T.: Ocean acidification and calcifying reef organisms: a mesocosm investigation, Coral Reefs, 27, 473483, doi:10.1007/s00338-008-0380-9, 2008.

Kayanne, H., Suzuki, A., and Saito, H.: Diurnal changes in the partial pressure of carbon dioxide in coral reef water, Science, 269, 214-216, 1995.

Kinsey, D. W.: Alkalinity changes and coral reef calcification, Limnol. Oceanogr., 23, 989-991, 1978.

Kleypas, J. A., Buddemeier, R. W., Archer, D., Gattuso, J.-P., Langdon, C., and Opdyke, B. N.: Geochemical consequences of increased atmospheric carbon dioxide on coral reefs, Science, 284, 118-120, 1999.

Kleypas, J. A., Feely, R. A., Fabry, V. J., Langdon, C., Sabine, C. L., and Robbins, L. L.: Impacts of ocean acidification on coral reefs and other marine calcifiers: a guide for future research, report of a workshop held 18-20 April 2005, St. Petersburg, FL, sponsored by NSF, NOAA, and the US Geological Survey, 2006.

Kuffner, I. B. and Paul, V. J.: Effects of nitrate, phosphate and iron on the growth of macroalgae and benthic cyanobacteria from Cocos Lagoon, Guam, Mar. Ecol. Prog. Ser., 222, 63-72, 2001.

Kuffner, I. B., Andersson, A. J., Jokiel, P., Rodgers, K. S., and Mackenzie, F. T.: Decreased abundance of crustose coralline algae due to ocean acidification, Nature Geosci., 1, 114-117, 2008. 
Langdon, C. and Atkinson, M.: Effect of elevated $p \mathrm{CO}_{2}$ on photosynthesis and calcification of corals and interactions with seasonal change in temperature/irradiance and nutrient enrichment, J. Geophys. Res., 110, C09S07 doi:10.1029/2004JC002576, 2005.

Langdon, C., Takahashi, T., Sweeney, C., Chipman, D., Goddard, J., Marubini, F., Aceves, H., Barnett, H., and Atkinson, M.: Effect of calcium carbonate saturation state on the calcification rate of an experimental coral reef, Global Biogeochem. Cy., 14, 639$654,2000$.

Leclercq, N., Gattuso, J.-P., and Jaubert, J.: Primary production, respiration, and calcification of a coral reef mesocosm under increased $\mathrm{CO}_{2}$ partial pressure, Limnol. Oceanogr., 47, 558-564, 2002.

Lewis, E. and Wallace, D. W. R.: Program Developed for $\mathrm{CO}_{2}$ System Calculations, ORNL/CDIAC-105: Carbon Dioxide Information Analysis Center, Oak Ridge National Laboratory, US Department of Energy, Oak Ridge, Tennessee, 1998.

Mackenzie, F. T., Lerman A., and Ver, L. M.: Recent past and future of the global carbon cycle, in: Geological Perspectives of Global Climate Change, AAPG Studies in Geology, edited by: Gerhard, L. C., Harrison, W. E., and Hanson, B. M., The American Association of Petroleum Geologists, Tulsa, 47, 51-82, 2001.

Martin, S. and Gattuso, J.-P.: Response of Mediterranean coralline algae to ocean acidification and elevated temperature, Glob. Change Biol., 15, 2089-2100, 2009.

Marubini, F., Ferrier-Pagés, C., and Cuif, J.-P.: Suppression of skeletal growth in scleractinian corals by decreasing ambient carbonate-ion concentration: a cross-family comparison, P. Roy. Soc. London B, 270, 179-184, 2003.

McDonald, M. R., McClintock, J. B., Amsler, C. D., Rittschof, D., Angus, R. A., Orihuela, B., and Lutostanski, K.: Effects of ocean acidification over the life history of the barnacle Amphibalanus amphitrite, Mar. Ecol. Prog. Ser., 385, 179-187, 2009.

McNeil, B. I., Matear, R. J., and Barnes, D. J.: Coral reef calcification and climate change: the effect of ocean warming, Geophys. Res. Lett., 31, L22309, doi:10.1029/2004GL021541, 2004.

Mehrbach, C., Culberson, C. H., Hawley, J. E., and Pytkowicz, R. M.: Measurement of the apparent dissociation constants of carbonic acid in seawater at atmospheric pressure, Limnol. Oceanogr., 18, 897-907, 1973.

Milliman, J. D.: Production and accumulation of calcium carbonate in the ocean: Budget of a nonsteady state, Global Biogeochem. Cy., 7, 927-957, 1993.

Milliman, J. D. and Droxler, A. W.: Neritic and pelagic carbonate sedimentation in the marine environment: ignorance is not bliss, Geol. Rundsch., 85, 496-504, 1996.

Morse, J. W., Andersson, A. J., and Mackenzie, F. T.: Initial responses of carbonate-rich shelf sediments to rising atmospheric $p \mathrm{CO}_{2}$ and ocean acidification: role of high $\mathrm{Mg}$-calcites, Geochim. Cosmochim. Acta, 70, 5814-5830, 2006.

Morse, J. W. and Mackenzie, F. T.: Geochemistry of sedimentary carbonates, Elseiver Science Publishing Co., 1990.

Ohde, S. and van Woesik, R.: Carbon dioxide flux and metabolic processes of a coral reef, Okinawa, B. Mar. Sci., 65, 559-576, 1999.
Orr, J. C., Fabry, V. J., Aumont, O., Bopp, L., Doney, S. C., Feely, R. A., Gnanadesikan, A., Gruber, N., Ishida, A., Joos, F., Key, R. M., Lindsay, K., Maier-Reimer, E., Matear, R., Monfray, P., Mouchet, A., Najjar, R. G., Plattner, G. K., Rodgers, K. B., Sabine, C. L., Sarmiento, J. L., Schlitzer, R., Slater, R. D., Totterdell, I. J., Weirig, M. F., Yamanaka, Y., and Yool, A.: Anthropogenic ocean acidification over the twenty-first century and its impacts on calcifying organisms, Nature, 437, 681-686, 2005.

Reynaud, S., Leclercq, N., Romaine-Lioud, S., Ferrier-Pagès, C., and Gattuso, J.-P.: Interacting effects of $\mathrm{CO}_{2}$ partial pressure and temperature on photosynthesis and calcification in a scleractinian coral, Glob. Change Biol., 9, 1660-1668, 2003.

Sabine, C. L., Feely, R. A., Gruber, N., Key, R. M., Lee, K., Bullister, J. L., Wanninkhof, R., Wong, C. S., Wallace, D. W. R., Tilbrook, B., Millero, F. J., Peng, T. -H., Kozyr, A., Ono, T., and Rios, A.: The oceanic sink for anthropogenic $\mathrm{CO}_{2}$, Science, 305, 367-371, 2004.

Schneider, K. and Erez, J.: The effect of carbonate chemistry on calcification and photosynthesis in the hermatypic coral Acropora eurystoma, Limnol. Oceanogr., 51, 1284-1293, 2006.

Silverman, J., Lazar, B., and Erez, J.: Effect of aragonite saturation, temperature, and nutrients on the community calcification rate of a coral reef, J. Geophys. Res., 112, C05004, doi:10.1029/2006JC003770, 2007.

Silverman, J., Lazar, B., Cao, L., Caldeira, K., and Erez, J.: Coral reefs may start dissolving when atmospheric $\mathrm{CO}_{2}$ doubles, Geophys. Res. Lett., 36, L05606, doi:10.1029/2008GL036282, 2009.

Smith, A. D. and Roth, A. A.: Effect of carbon dioxide concentration on calcification in the coralline alga Bossiella orbigniana, Mar. Biol., 52, 217-225, 1979.

Smith, S. V, Jokiel, P. L., Key, G. S., and Guinther, E. B.: Metabolic responses of shallow tropical benthic microcosm communities to perturbation, Environmental Protection Agency, Narragansett, Rhode Island, Final report of contract R800906, onlina available at: http://CRAMP.wcc.hawaii.edu/, 1977.

Smith, S. V. and Key, G. S.: Carbon dioxide and metabolism in marine environments, Limnol. Oceanogr., 20, 493-495, 1975.

Smith, S. V. and Kinsey, D. W.: Calcification and organic carbon metabolism as indicated by carbon dioxide, in: Coral reefs: research methods edited by: Stoddart, D. R. and Johannes, R. E., Monogr. Oceanogr. Methodol. 5. UNESCO, 469-484, 1978.

Tribollet, A.: The boring microflora in modern coral reef ecosystems: a review of its roles, in: Current Developments in Bioerosion, edited by: Wisshak, M. and Tapanila, L., Springer-Verlag Berlin Heidelberg, 2008.

Tribollet, A., Godinot C., Atkinson, M., and Langdon, C.: Effects of elevated $p \mathrm{CO}_{2}$ on dissolution of carbonates by microbial euendoliths, Global Biogeochem. Cy., 23, GB3008, doi:10.1029/2008GB003286, 2009.

Yates, K. K. and Halley, R. B.: $\mathrm{CO}_{3}^{2-}$ concentration and $p \mathrm{CO}_{2}$ thresholds for calcification and dissolution on the Molokai reef flat, Hawaii, Biogeosciences, 3, 357-369, 2006, http://www.biogeosciences.net/3/357/2006/.

Zeebe, R. E. and Wolf-Gladrow, D.: $\mathrm{CO}_{2}$ in seawater: equilibrium, kinetics, isotopes, Elseiver Science, 2003. 